\title{
Seasonal, annual, and spatial variation in the development of hard bottom communities*
}

\author{
J. Harms ${ }^{1} \&$ K. Anger ${ }^{2}$ \\ ${ }^{1}$ Zoologisches Institut, Technische Hochschule Darmstadt; \\ Schnittspahnstr. 10, D-6100 Darmstadt \\ ${ }^{2}$ Biologische Anstalt Helgoland (Meeresstation); \\ D-2192 Helgoland, Federal Republic of Germany
}

\begin{abstract}
The development of hard bottom communities has been studied on test panels in Helgoland Harbour (German Bight) since 1977. Settlement and growth of epibenthic species was examined monthly. Natural variation in different seasons, years, and at three stations (the latter, only in 1981 and 1982) was investigated. At Station A (Binnenhafen), barnacles (Balanus crenatus) and polychaetes (Polydora ciliata) were always among the first settlers in spring. They were followed by other barnacles (Elminius modestus, Balanus improvisus) and by colonial ascidians (Botryllus schlosseri). The latter species often dominated from August to October, and tended to overgrow the barnacle populations. E. modestus showed strong annual variation, probably due to extremely low winter temperatures: after the cold winter of 1978/79, its populations were less dense than in previous years. In 1981 they recovered, and settlement increased again, but the cold winter 1981/82 damaged the population again. At Station B (Nordosthafen), mussels (Mytilus edulis) soon covered barnacles and empty space. By October they had monopolized the fouling community. At Station C (Südhafen), barnacle settlement in spring was followed by an overgrowth of hydrozoans (Laomedea spec.). In summer, ascidians (Ciona intestinalis and Ascidiella aspersa) settled and began to dominate. Barnacles were weaker in the competition for space as opposed to later colonizers at all three stations.
\end{abstract}

\section{INTRODUCTION}

The colonization of artificial hard substratum has been studied on the island of Helgoland (German Bight, North Sea) since 1977. A preliminary report was given by Anger (1978), who also reviewed relevant literature.

The main purpose of this long-term investigation has been to analyze recurrent patterns in community development during the seasonal course of epibenthic colonization. The consequences to community structure of annual variation in recruitment success of potentially dominating species are one of the most interesting aspects of this study, since they may shed light on the effectiveness of interspecific interactions such as competition for space shaping epibenthic assemblages.

* Dedicated to the memory of Dr. J. A. Petersen (São Paulo, Brazil), who died on 11 February, 1983 in an accident during his work on hard bottom communities. 
Since 1981, the study has been extended to three stations located in different harbours of the island. Thus, spatial variation is also considered. This may contribute towards further knowledge of the competitive interactions and other factors influencing the direction of community development.

The present paper is an intermediate report on recurrent patterns and annual variation of seasonal epibenthic community development, and it is a preliminary account of spatial variation in these particular hard bottom communities.

\section{MATERIAL AND METHODS}

Wooden frames with 12 test panels $\left(100 \mathrm{~cm}^{2}\right.$ plexiglas) were suspended from rafts, so that they floated in a vertical position, ca 1 to $1.5 \mathrm{~m}$ below the water surface. The schedule for suspending and sampling the panels was described in detail by Anger (1978). Every month two panels were removed and the fouling communities were examined under a stereo microscope: one after being exposed for one month only, another one after being submerged since the beginning of the experiment ("Series A" panels). At Station A (Binnenhafen), experiments were conducted during the periods May 10, 1977 to May 11, 1978 (see Anger, 1978); May 17, 1978 to October 16, 1978; May 16, 1979 to October 13,1979; January 15, 1980 to November 15, 1980; March 9, 1981 to April 6, 1982, and from April 6, 1982. At Stations B (Nordosthafen) and C (Südhafen), colonization of the test panels has been studied since 1981 with the same investigation periods as above, in order to record spatial variation.

The density of individuals or colonies on one-month panels will be termed "primary

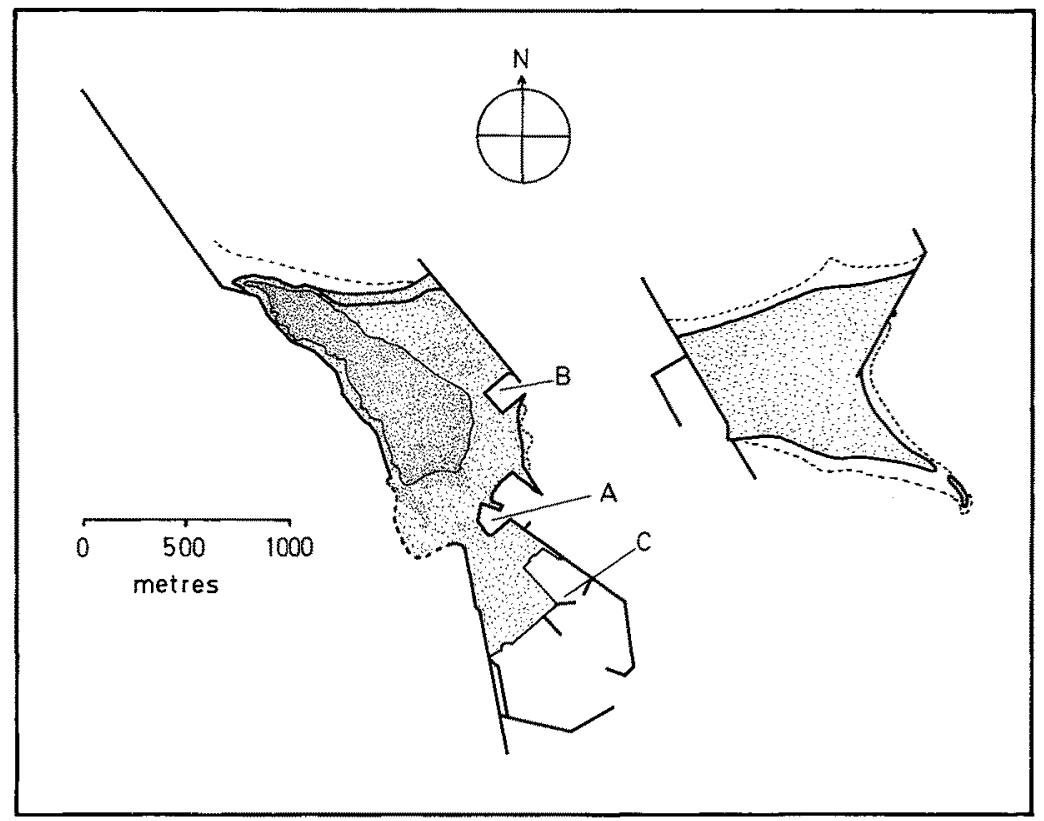

Fig. 1. The investigation area: Island of Helgoland (left; with Stations A, B, and C) and Düne Island (right) 


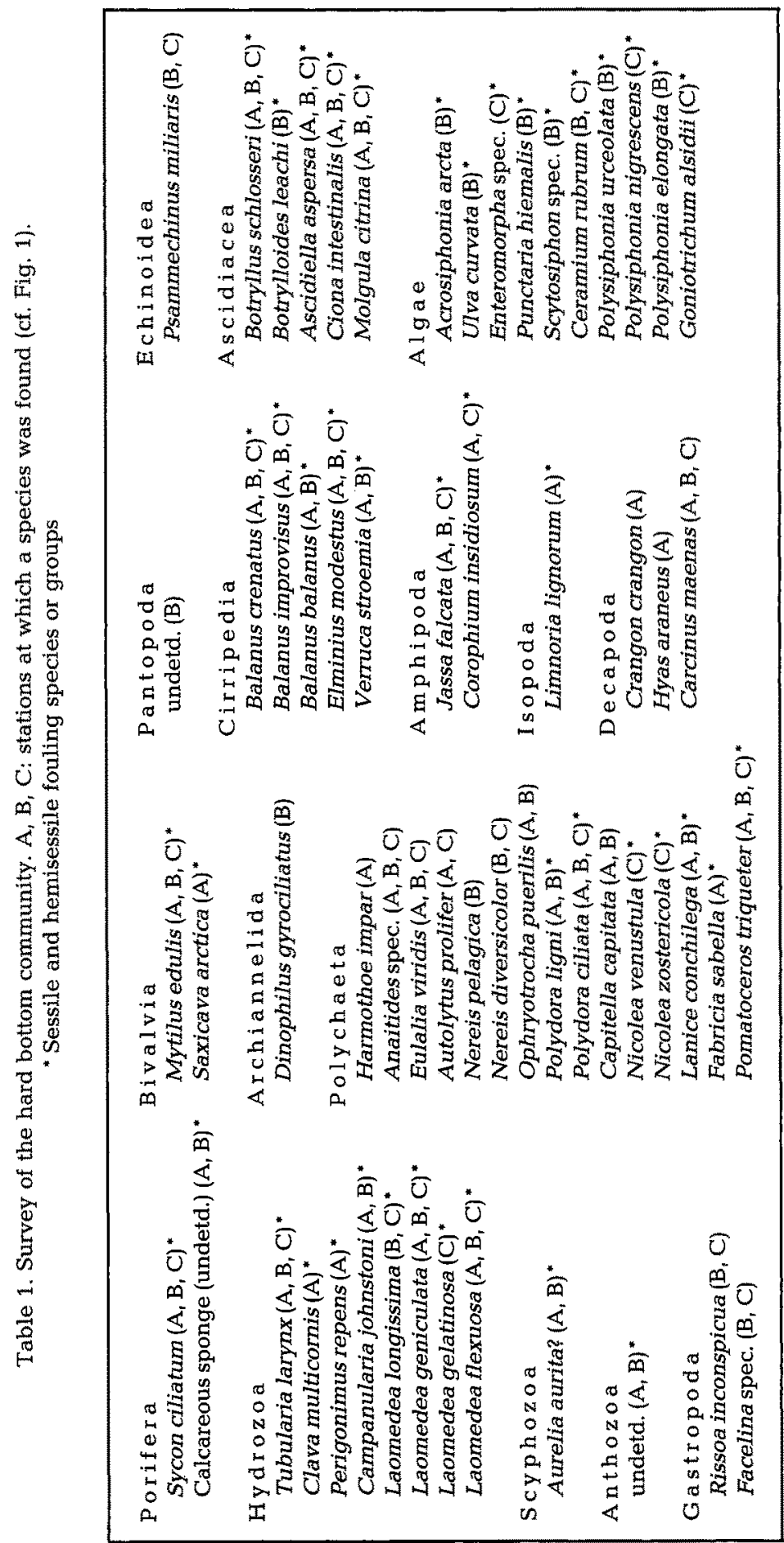


settling potential" (PSP). The numbers found on Series-A panels, where interactions between earlier and later colonizers took place and influenced settlement figures, will be referred to as "actual settling success" (ASS). This term applies both to organisms directly attached to the panels and to those attached to the surface of earlier settlers. PSP and ASS are not to be confused with "primary" and "secondary fouling assemblage" (PFA and SFA) sensu Field (1982). Figure 1 shows the investigation area with the stations. Stations A and B are exposed to strong tidal currents, which are increased by a funnel effect between Helgoland and Düne islands. Station $C$ is much more sheltered from both wave action and currents as opposed to A and B. More details on the methods applied were given by Anger (1978).

\section{RESULTS}

A survey of all major species and unidentified groups found since 1977 on test panels is given in Table 1 . Very small animals such as protozoans, harpacticoids, nematodes, turbellarians etc. were not identified and are thus not included in the survey. $70 \%$ of all animal taxa listed in Table 1 are sessile and hemisessile fouling organisms; $30 \%$ are motile, but more or less typical for fouling communities. 20 of 53 taxa were found at all three stations, 18 at two stations, and 15 at one station only. Stations A and B have 30 taxa (57\% of all) in common, B and C $25(47 \%)$, and A and C only $23(43 \%)$.

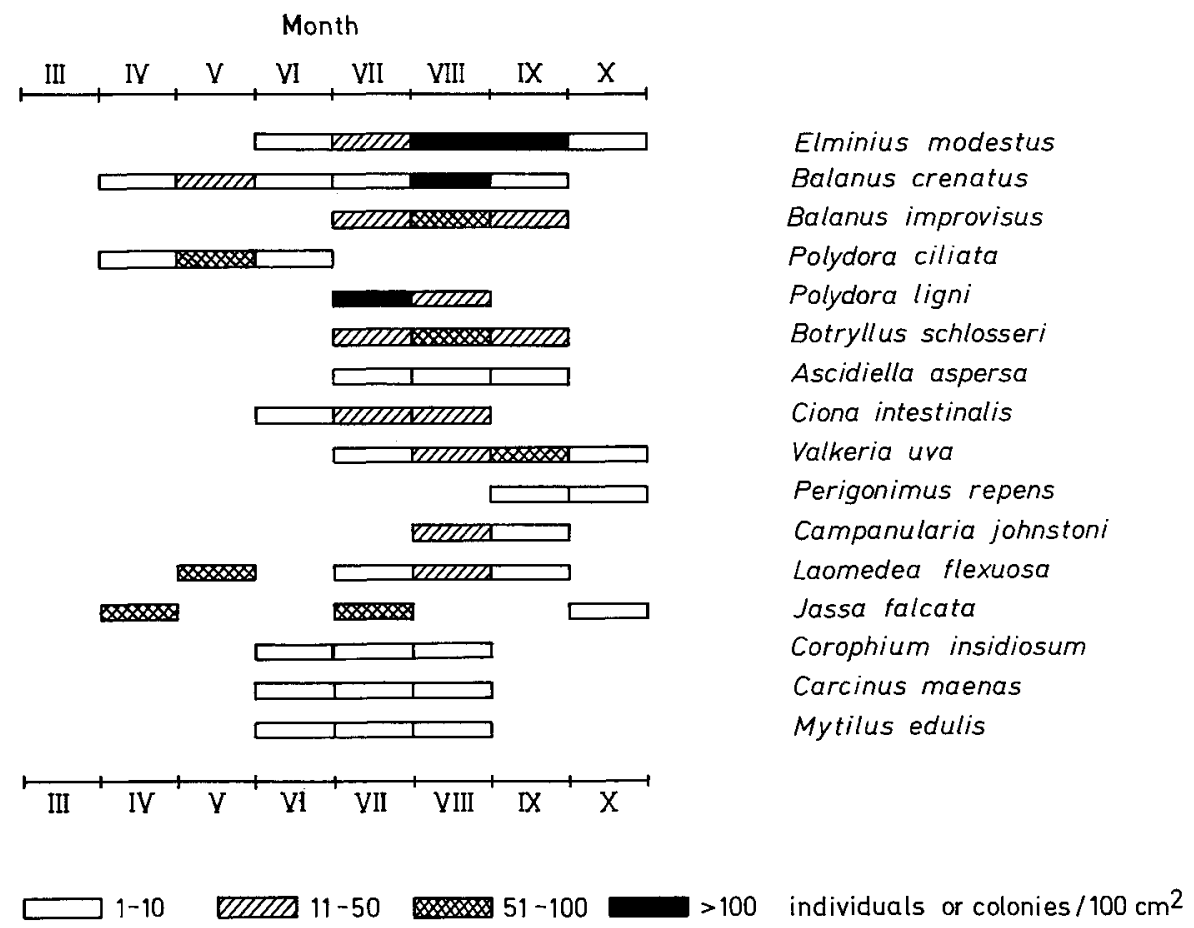

Fig. 2. Colonization period of the most prominent epibenthic species as observed on one-month panels 
Station A revealed the highest number of macroscopic taxa (41), followed by B (39) and C (31). These numbers suggest that, in qualitative terms, Stations A and B are more similar to each other than to Station $\mathrm{C}$, and their species richness is higher.

\section{Seasonal variation: The course of colonization}

Analysis of the one-month panels showed that in the course of colonization there was only little annual and spatial variation during the investigation period. Therefore, the observations made in different years and stations can be summarized as average PSP values, shown in Figure 2, to depict a typical settlement pattern. During the first three months of the year no macroscopic colonizers were recorded. Only protozoans, turbellarians and other microfauna made up a primary community during the winter season. Multicellular algae were generally absent on the panels and did not play any role as part of the epibenthic communities. Considerable algal settlement occurred only in 1982 at Stations B and C (Table 1): in June, Punctaria hiemalis started to settle at Station B, followed in July by Ceramium rubrum, whereas at Station C Enteromorpha spp. were most conspicuous. In August, C. rubrum became a dominant colonist at Station B, which was already colonized by Polysiphonia elongata and mussel spat (Mytilus edulis).

The first macroscopic animals generally settled in April: the barnacle Balanus crenatus, the polychaete Polydora ciliata, and the tube-building amphipod Jassa falcata. In the following month $B$. crenatus and $P$. ciliata increased their colonization activity accompanied by settling hydrozoans (Laomedea flexuosa).

Most species began to colonize the one-month panels during June and July. General settlement intensity was highest in July and August, thereafter it decreased, and in October it ceased (Fig. 2). The final colonizers were usually Elminius modestus, Valkeria uva, Perigonimus repens, and $J$. falcata.

Figure 3 shows seasonal changes of the fouling communities (ASS) at the three sites, compared in 1981. June, August, and October were chosen as examples of early,

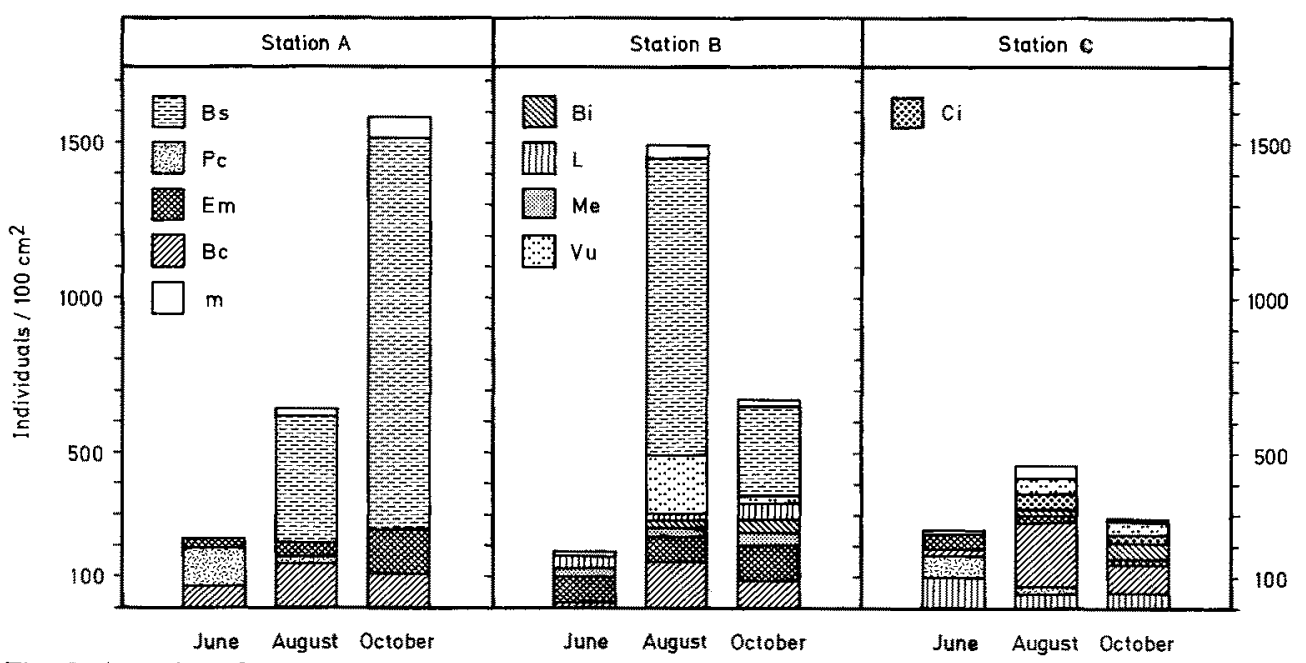

Fig. 3. Actual settling success (ASS) during the course of colonization at three stations. $\mathrm{Me}=\mathrm{My}$ tilus edulis, $\mathrm{Ci}=$ Ciona intestinalis; for abbreviations of other species names see Fig. 5 
intermediate, and late stages of community development. Specific differences between the stations are discussed below under the heading "Spatial variations".

At Station A, $P$. ciliata and B. crenatus clearly dominated in May and June. In the following two months, $E$. modestus, $B$. improvisus and $B$. schlosseri were the most successful colonizers changing the appearance of the community. Since the latter species is a colonial ascidian with highly intensive budding, it became increasingly dominant toward autumn. The same pattern of colonization was observed at Station $A$ in 1977 (Anger, 1978), 1978 and 1981, with a similar pattern in 1980 and 1982. Thus, 1981 may be considered a "typical" year for this station as well as for the other stations.

At Station B, amphipods (Jassa falcata) were dominant at the very beginning of colonization (April, May). In June and July, increasing numbers of barnacles (E. modestus, B. crenatus, B. improvisus), hydroids (L. flexuosa), and young mussels (Mytilus edulis) mainly constituted the fouling community. As at Station $A, B$. schlosseri overgrew most of these species in August, accompanied by successful settlement of Valkeria uva; however, the latter form was unable to grow on juvenile mussels. $M$. edulis began to dominate the community in late summer.

Station $\mathrm{C}$ was colonized first by $L$. flexuosa and P. ciliata. In June, E. modestus became co-dominant, as at the other stations. B. crenatus, B. improvisus, B. schlosseri, Ascidiella aspersa and Ciona intestinalis began to settle in July and occupied the last available free space. PSP of several species remained high until September, but ASS decreased, because $C$. intestinalis and $A$. aspersa grew very fast and soon covered most of the space. Like $M$. edulis at Station $\mathrm{B}$, these ascidians (mainly the former species) became dominant with a relatively low number of increasingly large-sized individuals.

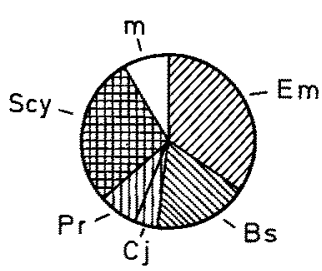

1977

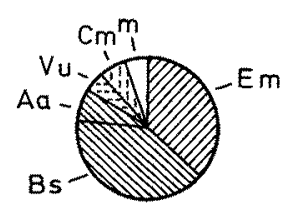

1978

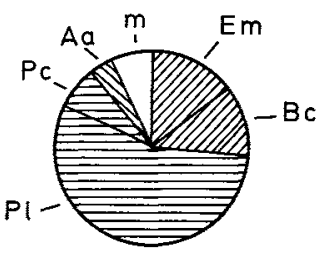

1979

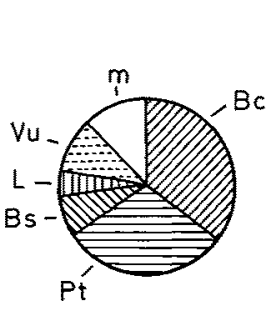

1980

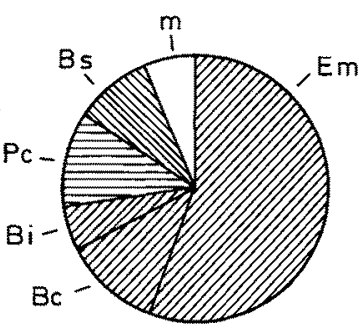

1981

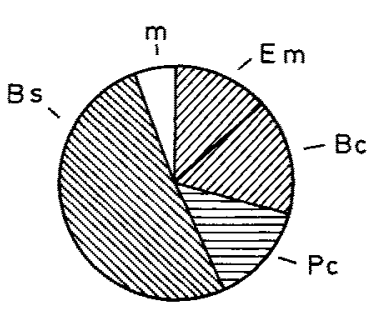

1982

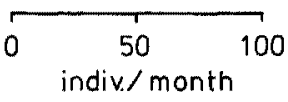

Fig. 4. Annual variation in average primary settling potential (PSP) at Station A. For abbreviations of species names see Fig. 5 


\section{Annual variation}

Annual variations in this general scheme of epibenthic recruitment can only be shown for Station A (Binnenhafen), which has been studied since 1977. At this site, colonization activity always started in April or May and lasted until October or November. PSP figures were summed up for these periods and monthly mean values (represented in Fig. 4 by diameters of circle diagrams) are used as a measure of total settlement intensity in a given year. The portions of the principal colonizers are shown as sectors.

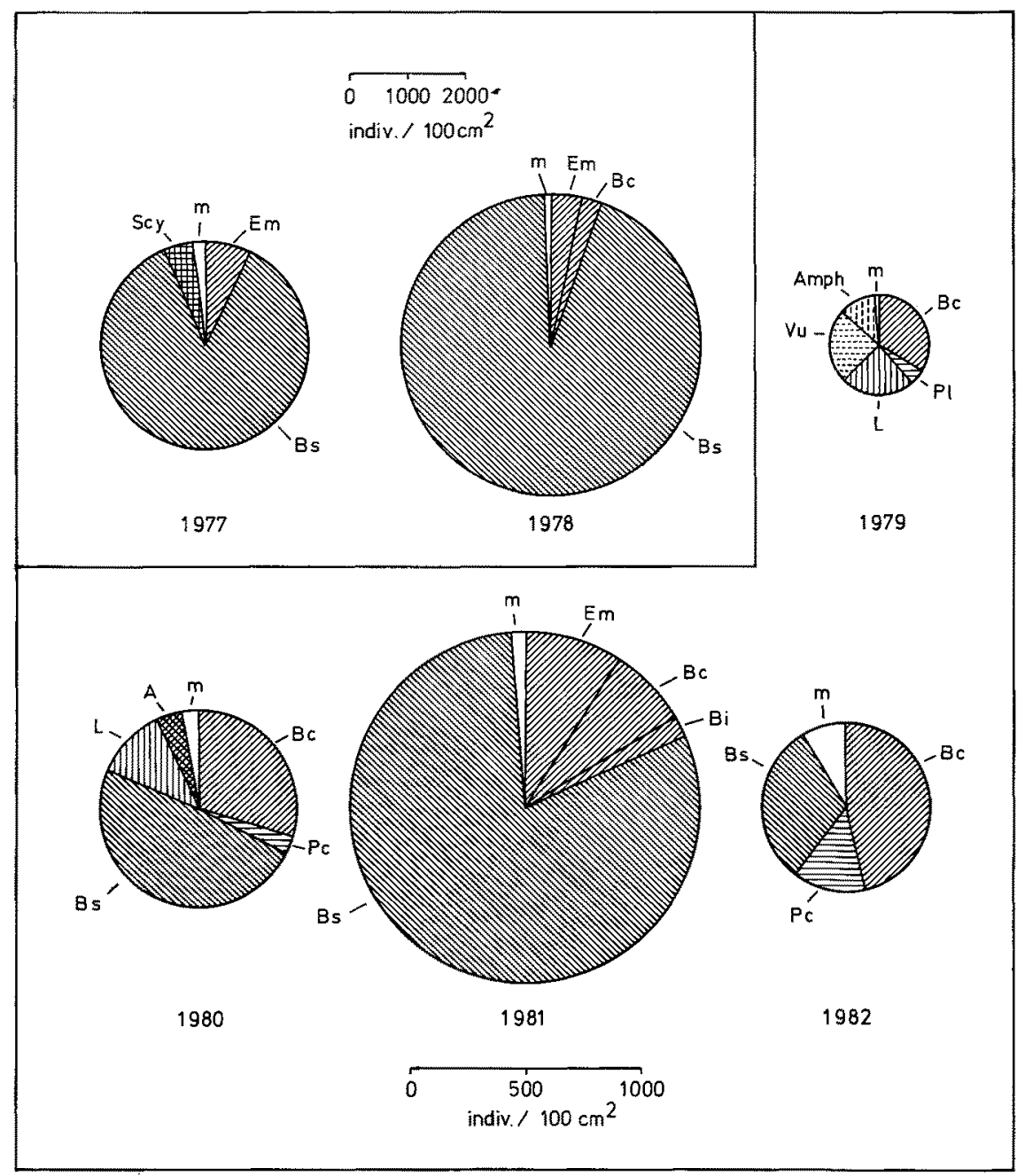

Fig. 5. Annual variation in actual settling success (ASS) in October at Station A. Em = Elminius modestus, $\mathrm{Bc}=$ Balanus crenatus, $\mathrm{Bi}=$ Balanus improvisus, $\mathrm{Pt}=$ Pomatoceros triqueter, $\mathrm{Pc}=$ Polydora ciliata, $\mathrm{Pl}=P$. ligni, $B s=$ Botryllus schlosseri, $\mathrm{Aa}=$ Ascidiella aspersa, $\mathrm{Pr}=$ Pergonimus repens, $\mathrm{Cj}=$ Campanularia johnstoni, $\mathrm{L}=$ Laomedea spec., $\mathrm{Scy}=$ Scyphozoa, $\mathrm{Vu}=$ Valkeria uva, $\mathrm{Amph}=$ Amphipoda, $\mathrm{A}=$ Anthozoa, $\mathrm{Cm}=$ Carcinus maenas, $\mathrm{m}=$ miscellaneous 
Figure 4 shows that $E$. modestus and $B$. schlosseri had a very high PSP in all years except in 1979 and 1980. E. modestus showed weak settlement in 1982 as well. Scyphozoan polyps (most probably Aurelia aurita) were among the most abundant colonizers only in 1977 (see Anger, 1978), Polydora ciliata in 1981 and 1979. All other species played a minor role as primary colonizers at Station A.

Total colonization intensity, expressed as mean total PSP (Fig, 4), was highest in 1981, and lowest in 1978: 106 and 56 individuals per month per $100 \mathrm{~cm}^{2}$, respectively. During the settlement periods in the other three years it was close to the average (76 individuals per month and panel).

Annual variation in the primary settling potential as shown above is the main source of variation in community composition observed at the end of the colonization period (in autumn). Since in October and November there was no (or negligible) settlement of macroscopic organisms, the actual settling success (ASS) at the beginning of October was used as a measure of resulting community structure (Fig. 5).

The difference between PSP (Fig. 4) and ASS (Fig. 5) is striking: E. modestus was one of the most successful primary settlers, but by the end of the colonization period (Fig. 5) it was always more or less supplanted. Usually it was overgrown by budding colonies of B. schlosseri during August and September. In 1979 and 1980, when both $E$. modestus and $B$. schlosseri had much lower success than in the other years, $B$. crenatus became a dominant species, and the community had a higher species diversity. Total colonization figures (numbers of individuals found per $100 \mathrm{~cm}^{2}$ in October) were mainly influenced by $B$. schlosseri. In 1977 and 1978, when this species had very high PSP (cf. Fig. 4), it became overwhelmingly dominant until the end of the colonization period showing extremely high "individual" numbers (ASS, Fig. 5). In 1982, B. crenatus and $B$. schlosseri were co-dominants. As an exception, the latter species was not able to supersede the former in that year.

The annual variation in colonization success of $E$. modestus and $B$. crenatus is also shown in Figure 6 . The patterns of variation suggest that temperature during the winter season may be a key factor for the recruitment of E. modestus and B. schlosseri: their low PSP and ASS figures in 1979, 1980, and 1982 (cf. Figs. 4 and 5) coincided with obvious damage to natural populations caused by the exceptionally cold winters $1978 / 79$ and $1981 / 82$.

B. crenatus also showed large variations in ASS figures (Fig. 6), which are apparently inversely related to variations in E. modestus and B. schlosseri. B. improvisus has appeared in the fouling community only during the last three years (1980-82). The settlement periods in these years often revealed particularly low salinities (below $30 \%$ ). This may be considered an indicator for estuarine influence favouring brackish water barnacle species.

\section{Spatial variation}

Figure 3 shows the course of colonization (ASS) at all three stations in 1981. Mean total PSP was far higher at Stations B and C than at Station A (averages for the settlement period: 191, 153, and 106 individuals per month per panel, respectively). Elminius modestus revealed the highest PSP of all species at all sites, but to a considerably lesser degree at Station C. Barnacles as a group were potentially dominant to a similar extent at 
all sites compared. The rest of the settling fauna was quite different in the three harbours: Polydora ciliata and Botryllus schlosseri settled heavily at Station A, amphipods (mainly Jassa falcata) and Valkeria uva at Station B, and Laomedea spec. (mainly L. flexuosa) and Ciona intestinalis at Station C.

When the actual settling success (Fig. 3) is considered, it is obvious that the communities at the three localities developed in completely different ways (cf. section headed "Seasonal variation: the course of colonization"), although the distances between them are very small (Fig. 1). At the end of the settlement period, in October, $B$. schlosseri covered ca $40 \%$ of the community surface at Station $A_{;}$it had overgrown many barnacles, which had already colonized almost $100 \%$ of all available primary space on the panels. E. modestus, $B$. crenatus, and to a lesser degree $B$. improvisus were codominant. At Station B, Mytilus edulis covered almost the whole surface and began to overgrow the underlaying, co-dominant species (B. schlosseri, E. modestus, B. crenatus, $B$. improvisus, and L. flexuosa). At Station $C$, the solitary ascidian C. intestinalis reached a body size of ca $3 \mathrm{~cm}$ in August, and in October it had overgrown all other species (mainly B. crenatus and B. improvisus, with E. modestus, L. flexuosa, and V. uva in smaller amounts).

\section{Patterns of competition for space}

Biological interactions in developing fouling communities can be analyzed by direct comparison of PSP and ASS figures. One example is the Mytilus edulis settlement at Station B: mussel spat did not occur on the one-month panels, thus showing extremely low PSP. Dense settlement took place only on older panels already colonized by hydroids or algae. In late summer, mussels began to cover the underlayer of barnacles, ascidians and other early colonizers. Although there was only a relatively small number of $M$. edulis, they severely changed the community structure due to their increasingly large body size.

Solitary ascidians (Ciona intestinalis, Ascidiella aspersa) did not depend on primary settlers, but they also were superior competitors, due to their fast body growth. The rate of monopolization (ASS) was in this case (in contrast to $M$. edulis) positively linked with their PSP.

Figure 6 shows cumulative PSP as opposed to ASS figures in two barnacle species (Elminius modestus and Balanus crenatus) during five years at Station A. In 1977 (Anger, 1978 ) and $1978, E$. modestus showed higher ASS than PSP values. In these years, $B$. crenatus had only little settlement success. After the cold winter 1978/79, the latter species became dominant, with ASS surpassing PSP (1979 and 1980). In the following year, when $E$. modestus was successful again with very high PSP, the two species became equally strong competitors (about equal ASS). After another cold winter, in 1982, E. modestus was again much less successful, and $B$. crenatus had much higher ASS than PSP.

In Figure 6 a the recurrent pattern is conspicuous: when there is clear dominance of one barnacle species (i.e. in all years except in late 1981), ASS of this dominant species is higher than its PSP. Anger (1978) related this mechanism to intraspecific aggregation during settlement. When ASS is lower than PSP, this indicates strong competition by another species. In the two barnacle species considered here, this appears to hold true up 


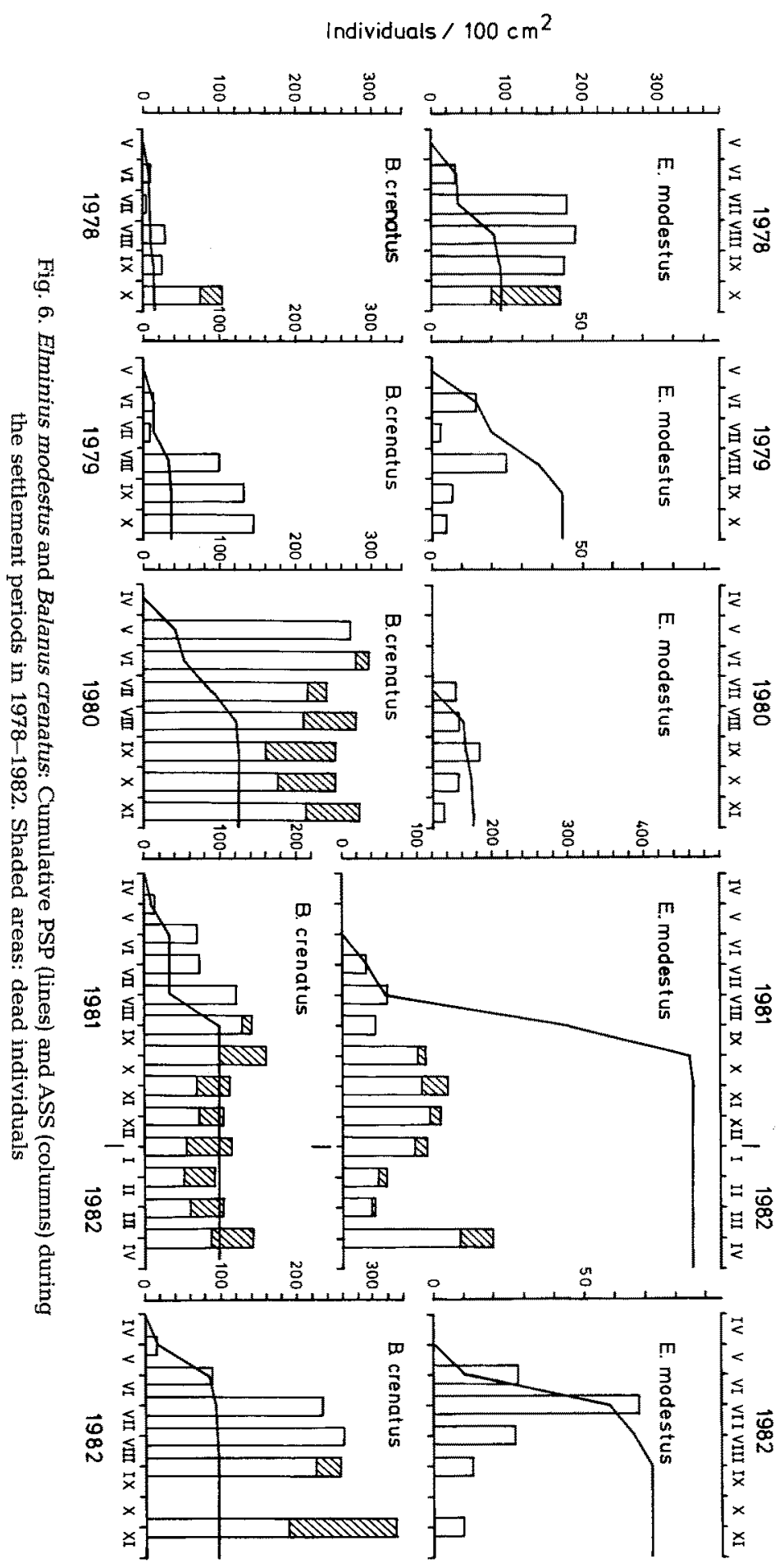


to an ASS limit of ca 300 individuals per plate, for both species combined (Fig. 6). This is probably the maximum capacity for settlement and growth of barnacles on the plate surface provided here.

Increasing numbers of dead barnacles are an indication of both intra-and interspecific competition. The patterns shown in Figure 6 suggest that barnacle competition (E. modestus vs $B$. cranatus) is mainly effective as an inhibition of settlement by already established juveniles of the opponent species. Competition between barnacles and Botryllus schlosseri takes place later: Even when PSP of this colonial ascidian was low (1980, 1981), its budding always caused relatively high ASS. Monopolization by this species was prevented only when it had no settlement success at all (e.g. at Station A, 1979).

\section{DISCUSSION}

Our observations on annual variations in the development of fouling communities (Figs 5 and 6) support the "multiple stable points" concept (Lewontin, 1969; for general discussion see Sutherland, 1974): in early successional stages, barnacles, hydroids, and tube-building polychaetes were often found to show high primary settling potential (PSP). Later development of the community, however, depended less on PSP of all colonizers in general, and more on the recruitment success or failure of a few superior competitors for space (key species). In the case presented here, quite different organisms tended to dominate established fouling communities after colonization ceased, these being intensively budding colonial ascidians (Botryllus schlosseri) at Station A, fast growing mussels (Mytilus edulis) at Station B, and solitary ascidians also showing high individual growth rates (Ciona intestinalis) at Station $\mathrm{C}$.

These species are superior not only on account of their potentially large body or colony size, but also due to defense mechanisms against overgrowth. Later colonizers are rarely able to settle on the soft tissues of ascidians or on the periostracum of juvenile mussels. This is different in old colonies or individuals, whose surface appears to be rougher and, as has already been observed, can be colonized by other fouling species. This, however, cannot play a role until the next colonization period (spring). Experiments running over periods longer than one year were initiated in 1981 to analyze longer-term cycles and possible stable points in community development.

The main dominants found on panels at Helgoland are well known from the literature to exhibit competitive superiority on hard bottom substrata in other areas: $B$. schlosseri in New Zealand (Luckens, 1976), New England (Field, 1982; Grosberg, 1981; Osman, 1977), and on British coasts (Fry, 1975; Withers \& Thorp, 1977). Fry (1975) observed, however, that other colonial tunicates (Diplosoma listerianum) were even superior to $B$. schlosseri. The generally high competitive potential in colonial species was discussed by Jackson (1977).

Also $C$. intestinalis, due to its fast growth and resistance to overgrowth (see above), can outcompete its encrusting relative $B$. schlosseri (Withers \& Thorp, 1977; Station C at Helgoland). Gulliksen (1980) found it "of crucial importance for the overall fauna composition" in a Norwegian fjord. Other solitary ascidians have been reported to show similar competitive ability: Molgula manhattansis (Fry, 1975; Dean \& Hurd, 1980), Dendrodoa grossularia (Gulliksen, 1975), Ascidiella aspersa (this study), and a number 
of other species can dominate fouling assemblages (Sutherland, 1974; Osman, 1977; Marshall et al., 1980).

Mussels (Mytilus edulis) characterized established communities and, possibly, the stable point at Station B at Helgoland. As described by Dean \& Hurd (1980), they are able to inhibit colonization by other potential dominants, and due to their rapid growth, relatively few individuals can compete successfully against them once they are settled. We observed that $M$. edulis growing inside empty barnacle shells and in crevices between living barnacles mechanically broke off their neighbours due to their body growth and so they created new free space. In this way, a mosaic patchwork was produced for a period of time. The mussels, however, soon occupied all available space, created by themselves.

As with $B$. schlosseri and $C$. intestinalis, the young $M$. edulis community is an example of the "inhibition model" of colonization (for recent discussion of theoretical concepts see Horn, 1974; Connell \& Slatyer, 1977; Sutherland \& Karlson, 1977; Dean \& Hurd, 1980) but at the same time it supports the contrary "facilitation model": its own primary settlement potential (PSP) on one-month panels was practically zero. Only after hydrozoans (Laomedea flexuosa and other species) or red algae (mainly Ceramium rubrum) in 1982 had established themselves, was settlement observed on these primary colonizers. This effect has been shown by De Blok \& Geelen (1959) and Bayne (1964) who found that filamentous structures are necessary for primary settlement of mussel spat. Secondary settlement on hard substrata takes place later, in this case on the plexiglas surface of the panels or on barnacles. Dean \& Hurd (1980) observed that settlement of $M$. edulis was promoted by earlier colonists, but on asbestos cement panels, for example, hydroids etc. were not necessary for the mussels. This may be explained by the different surface qualities of the panels employed by those authors and the ones used in the present study.

Stochastic events can interfere with biotic interactions: extraordinarily cold winters presumably suppress both the late dominant $B$. schlosseri and the barnacle E. modestus, which regularly dominate earlier stages of community development. In particular the cold winter 1978/79 had severe consequences for shallow water marine life in the German Bight (Dörjes, 1980). We have no information on the temperature tolerance of B. schlosseri, but our observations suggest that its populations suffered detrimental influence from unusually cold water. In $E$. modestus, the presumption of such an effect is supported by its geographic origin (it is a warm-water species introduced from Australian waters only recently), by the findings of Ritz \& Foster (1968) on its temperature tolerance, and by observations reported by Stubbings \& Houghton (1964). The latter authors suggested a relationship between recruitment success and water temperature in March, when the species is breeding. This corresponds well to the fact that the cold winters $1978 / 79$ and $1981 / 82$ were characterized by extremely low temperatures in January to March or April.

Salinity, too, may influence the settlement success of potential dominants: we suggest that the appearance of Balanus improvisus is favoured by low salinities. These may either stimulate its reproduction, favour larval survival or metamorphosis, or they are simply an indicator of estuarine water bodies carrying larvae from brackish areas.

Another example of climatic influence is provided by a recent observation: unlike previous years, there was in 1982 considerable algal settlement at Stations B and C. This 
may be explained by high light intensities due to the unusually calm and sunny weather conditions during this summer. Station $\mathrm{A}$ is situated in an area where research vessels, lying at berth, shade the panels most of the time. Presumably, this circumstance prevented algal growth there.

At an isolated rocky island such as Helgoland, the settlement of larvae transported from elsewhere can also be considered a stochastic event highly influencing community development. The success of scyphopolyps in 1977 may serve as an example for such an irregular effect.

Some biological interactions between early and late colonizers (i.e. between primary and secondary fouling assemblages sensu Field, 1982), and between successfully settled fouling species during the later course of community development could preliminarily be analyzed by comparison of PSP and ASS figures. Further information on colonization and growth strategies, on effects of stochastic events and on interactions in shaping the community will be derived from continuing experiments in Helgoland harbours.

Acknowledgements. The authors wish to thank all colleagues who helped from time to time in suspending or sampling panels. Mr. P. H. Sahling identified the algae. Mr. K. Treutner and Mr. P. Mangelsdorf provided unpublished temperature data. Mr. M. Wichers built frames and panels, and Mrs. B. Lämmel made the drawings. Our thanks are also due to Dr. J, Bolton for correcting the manuscript.

\section{LITERATURE CITED}

Anger, K., 1978. Development of a subtidal epifaunal community at the island of Helgoland. Helgoländer wiss. Meeresunters. 31, 457-470.

Bayne, B. L., 1964. Primary and secondary settlement in Mytilus edulis L. (Mollusca). - J. Anim. Ecol. 33, 513-523.

Blok, J. W. de \& Geelen, H. J. F. M., 1959. The substratum required for the settling of mussels (Mytilus edulis L.). - Archs néerl. Zool. 13 (Suppl. 1), 446-460.

Connell, J. H. \& Slatyer, R. O., 1977. Mechanisms of succession in natural communities and their role in community stability and organization. - Am. Nat. 111, 1119-1144.

Dean, T. A. \& Hurd, L. E., 1980. Development in an estuarine fouling community; the influence of early colonists on later arrivals. - Oecologia 46, 295-301.

Dörjes, J., 1980. Auswirkungen des kalten Winters 1978/79 auf das marine Macrobenthos. - Natur Mus., Frankf. 110, 109-115.

Field, B., 1982. Structural analysis of fouling community development in the Damariscotta River estuary, Maine. - J. exp. mar. Biol. Ecol. 57, 25-33.

Fry, W. G., 1975. Raft fouling in the Menai Strait. - Hydrobiologia 47, 527-558.

Grosberg, R. K., 1981. Competitive ability influences habitat choice in marine invertebrates. Nature, Lond. 290, 700-702.

Gulliksen, B., 1975. The macrobenthic fauna of rocks and boulders in the Lübeck Bay (Western Baltic Sea) investigated from the Underwater Laboratory "Helgoland". - Helgoländer wiss. Meeresunters. 27, 439-449.

Gulliksen, B., 1980. The macrobenthic rocky-bottom fauna of Borgenfjorden, North-Tröndelag, Norway. - Sarsia 65, 115-136.

Horn, H. S., 1974. The ecology of secondary succession. - A. Rev. Ecol. Syst. 5, 25-37.

Jackson, J. B. C., 1977. Competition on marine hard substrate: the adaptive significance of solitary and colonial strategies. - Am. Nat. 111, 743-767.

Lewontin, R. C., 1969. The meaning of stability. - Brookhaven Symp. Biol. 22, 13-24.

Luckens, P. A., 1976. Settlement and succession on rocky shores at Auckland, North Island, New Zealand. - Mem. N. Z. oceanogr. Inst. 70, 5-64. 
Marshall, J. J., Rowe, F. W. E., Fisher, R. P. \& Smith, D. F., 1980. Alterations to the relative speciesabundance of ascidians and barnacles in a fouling community due to screens. - Aust. J, mar. Freshwat. Res. 31, 147-153.

Osman, R. W., 1977. The establishment and development of a marine epifaunal community, - Ecol. Monogr. 47, 37-63.

Ritz, D. A. \& Foster, B. A., 1968. Comparison of the temperature responses of barnacles from Britain, South Africa and New Zealand, with special reference to temperature acclimation in Elminius modestus. - J. mar. biol. Ass. U. K. 48, 545-558.

Stubbings, H. G. \& Houghton, D. R,, 1964. The ecology of Chichester Harbour, S. England, with special reference to some fouling species, - Int. Revue ges. Hydrobiol. 49, 223-279.

Sutherland, J. P., 1974. Multiple stable points in natural communities. - Am. Nat, 108, 859-873.

Sutherland, J. P. \& Karlson, R. H., 1977. Development and stability of the fouling community at Beaufort, North Carolina. - Ecol. Monogr. 47, 425-446.

Withers, R. G. \& Thorp, C. H., 1977. Studies on the shallow, sublittoral epibenthos of Langstone harbour, Hampshire, using settlement panels. In: Biology of benthic organisms. Ed. by B. F. Keegan, P. O. Ceidigh \& J. P. S. Boaden. Pergamon Press, Oxford, 595-604. 